Journal of Sea Research

September 2016, Volume 115, Pages 33-46

http://dx.doi.org/10.1016/j.seares.2016.07.003

http://archimer.ifremer.fr/doc/00345/45606/

(c) 2016 Elsevier B.V. All rights reserved.

\title{
Feeding strategy of Downs herring larvae (Clupea harengus L.) in the English Channel and North Sea
}

\author{
Denis Jeremy ${ }^{1}$, Vallet Carole ${ }^{2,3}$, Courcot Lucie ${ }^{2}$, Lefebvre Valérie ${ }^{1}$, Caboche Josselin ${ }^{1}$, \\ Antajan Elvire ${ }^{1}$, Marchal Paul ${ }^{1}$, Loots Christophe ${ }^{1,{ }^{*}}$
}

${ }^{1}$ IFREMER, Channel and North Sea Fisheries Research Unit, 150 quai Gambetta, F-62321 Boulognesur-Mer, France

${ }_{2}^{2}$ Univ. Littoral Côte d'Opale, UMR 8187 CNRS - LOG, Laboratoire d'Océanologie et de Géosciences, Univ. Lille, F-62930, Wimereux, France

${ }^{3}$ Ecole Supérieure du Professorat et de l'Education - Lille Nord de France, Communauté d'Universités et d'Etablissements, F -59658 Villeneuve d'Ascq, France

*Corresponding author : Christophe Loots, email address : christophe.loots@ifremer.fr

\begin{abstract}
:
This study aims to characterize the larval feeding strategy of the Downs sub-population of North Sea herring (Clupea harengus L.). Diet composition, vacuity rate and prey selectivity of larvae from 8 to $15 \mathrm{~mm}$ collected during the International Bottom Trawl Survey (IBTS) - MIK sampling from 2008 to 2013 were assessed by direct observation of their gut contents using Scanning Electron Microscopy (SEM). The high contribution of protists and small zooplanktonic prey observed in the gut contents proved the relevance of SEM to study the diet of first feeding larvae. The relatively low vacuity rate of $45 \%$ suggests that food may not be a limiting factor for Downs herring larvae in winter. These larvae appeared to be omnivorous and there was a clear shift in term of prey composition at a size of $13 \mathrm{~mm}$. Smaller larvae (8-12 $\mathrm{mm}$ ) fed on a higher diversity of small prey, mainly small copepods (Oncaea spp. and Euterpina acutifrons), invertebrate eggs, diatoms (Psammodicthyon panduriforme and Coscinodiscus spp.) and dinoflagellates (Dinophysis acuminate and Prorocentrum micans) whereas bigger larvae (13-15 mm) fed on a lower diversity of larger prey, mainly copepods (Temora longicornis and Paracalanus parvus) and dinoflagellates (Gonyaulax spp.). Downs herring larvae had clear prey preferences as some dinoflagellates (Pyrophacus spp., Gonyaulax spp., P. micans and Porocentrum lima), invertebrate eggs, copepods (Oncaea spp. and nauplii) and diatoms (Thalassiosira curviseriata) were positively selected and other diatoms (Nitzschia spp., Thalassiosira tenera, Thalassiosira spp. and Chaetoceros spp.) and copepods (Pseudocalanus elongatus, T. Iongicornis and Unidentified calanoid) were negatively selected. We argue that this shift in term of prey preferences occurring at a size of $13 \mathrm{~mm}$ constitutes the critical period for Downs herring larvae.
\end{abstract}




\section{Highlights}

- Downs larvae are not more limited by winter trophic conditions than other species. Downs herring larvae are omnivorous and feed on a high diversity of prey. Very small protist highly contribute to the diet of 8-12 mm Downs larvae. The ontogenetic dietary shift observed at $13 \mathrm{~mm}$ constitutes the critical period. Scanning Electron Microscopy is essential to study the diet of first feeding larvae.

Keywords : Diet, Feeding strategy, Selectivity index, Scanning electronic microscopy, Downs herring larvae, Gut content

\section{Introduction}

For most of the species, fish larvae ensure the spatial linkage between the offshore spawning grounds occupied by adults and the coastal nurseries of juveniles (Harden-Jones, 1968). According to the -critical periodll hypothesis of Hjort (1914), they also have a determinant role in the recruitment of fish populations. Indeed, the year-class strength would be determined during a very short period called the -critical periodll when fish larvae shift from an endogenous to an exogenous nutrition. Their planktonic character make them highly reliant upon the environmental (both physics and trophic) conditions they experience during their drift. Larval growth and survival are affected by larval nutritional condition, which in turn depends on prey availability and quality during the first feeding stages (Cushing, 1969; Hjort, 1914; Houde, 2008; Lasker, 1975). Several authors also emphasize the key role of fish larvae in the pelagic food web (Bacha and Amara, 2009; Beaugrand et al., 2003; Bergeron, 2009; Duarte and Garcia, 2004; Fauchald et al., 2011) which may be due to their occurrence at a short and particular time period of the year. 
To promote the survival and growth of their larvae, most of fish species in the English Channel and North Sea reproduce during the spring period which ensures a temporal match of their larvae with the planktonic bloom (Match-Mismatch Hypothesis; Cushing, 1969). On the contrary, North Sea herring is one of the rarest species which reproduces during autumn and winter. It plays a key role in the North Sea ecosystem and has served for more than a century (Hjort, 1914) as the basis of the main ecological theories dedicated to fish larvae (Cushing, 1969; Houde, 2008; Iles and Sinclair, 1982). It also has a huge economical interest and represents half of the pelagic fish landings (in terms of weight) in the North Sea (ICES, 2015). From an ecological point of view, it is a complex species, including four main spawning components which reproduce in four different areas and at different times of the year. Three of them (Orkney-Shetland, Buchan and Banks) reproduce in the North Sea during Autumn whereas the fourth, called the Downs component, reproduces during winter in the Eastern English Channel (ECC) and Southern Bight of the North Sea (SBNS) (Corten, 2013, 1986; Heath, 1993; Heath et al., 1997; Maucorps, 1969). Since 2002, North Sea herring has experienced a poor recruitment despite a high biomass of mature fishes (Payne et al., 2009). Recently, Corten (2013) discussed the potential reasons for this low recruitment, including a poor larval feeding, an increase in the predation by herring adults, poor hatching conditions, a regime shift in the planktonic communities of the North Sea (Alvarez-Fernandez et al., 2012; Beaugrand et al., 2003) and an increase of larval mortality resulting from the recent increase of water temperatures (Becker and Pauly, 1996; Fässler et al., 2011; Hufnagl and Peck, 2011; Petitgas et al., 2013). Corten (2013) also argues that these recent changes may had favoured the larvae of the Downs component over those of the three North Sea components which could explain its recent contribution to the global population (ICES, 2015; Payne, 2010). 
According to Hjort, (1914), Nash and Dickey-Collas (2005), Fässler et al. (2011) and Payne et al. (2013), North Sea herring recruitment was shown to be determined during the first 20 days of the larval phase. During this period, Downs herring larvae experience the trophic conditions of the winter period, which is a clear example of mismatch as defined by Cushing (1969). Recruitment success of Downs herring then depends upon the overwintering mortality of its larvae for which prey availability seems to be important (Hufnagl et al., 2015). If one wants to better understand the role of prey availability on the Downs herring recruitment and predict its impact in a changing environment, the diet composition of Downs herring larvae should be firstly assessed. The Downs component is by far the least studied of the four North Sea components. This is even more true for the larval phase for which only few and non-recent field studies on its feeding strategy have been conducted (Lebour, 1924, 1921).

The main objective of this study is then to characterize the feeding strategy of Downs herring larvae during the winter period based on gut contents analysis using SEM as proposed by Koubbi et al. (2007), Montagnes et al. (2010) and Vallet et al. (2011). The study was carried out using data collected regularly in the EEC and SBNS over the period 2008-2013.

\section{Material and methods}

\subsection{Field sampling}

Hydro-biological parameters, protists (auto- and heterotroph unicellular organisms), mesozooplankton and Downs herring larvae were collected over the period 2008-2013 during the first quarter (January-February) of the French part of the IBTS, in the EEC and SBNS (Fig. 1). The sampling strategy of the IBTS (ICES, 2015) is stratified according to 
statistical rectangles of $1^{\circ}$ longitude $\times 0.5^{\circ}$ latitude. Each rectangle is sampled either twice (SBNS) or four times (EEC).

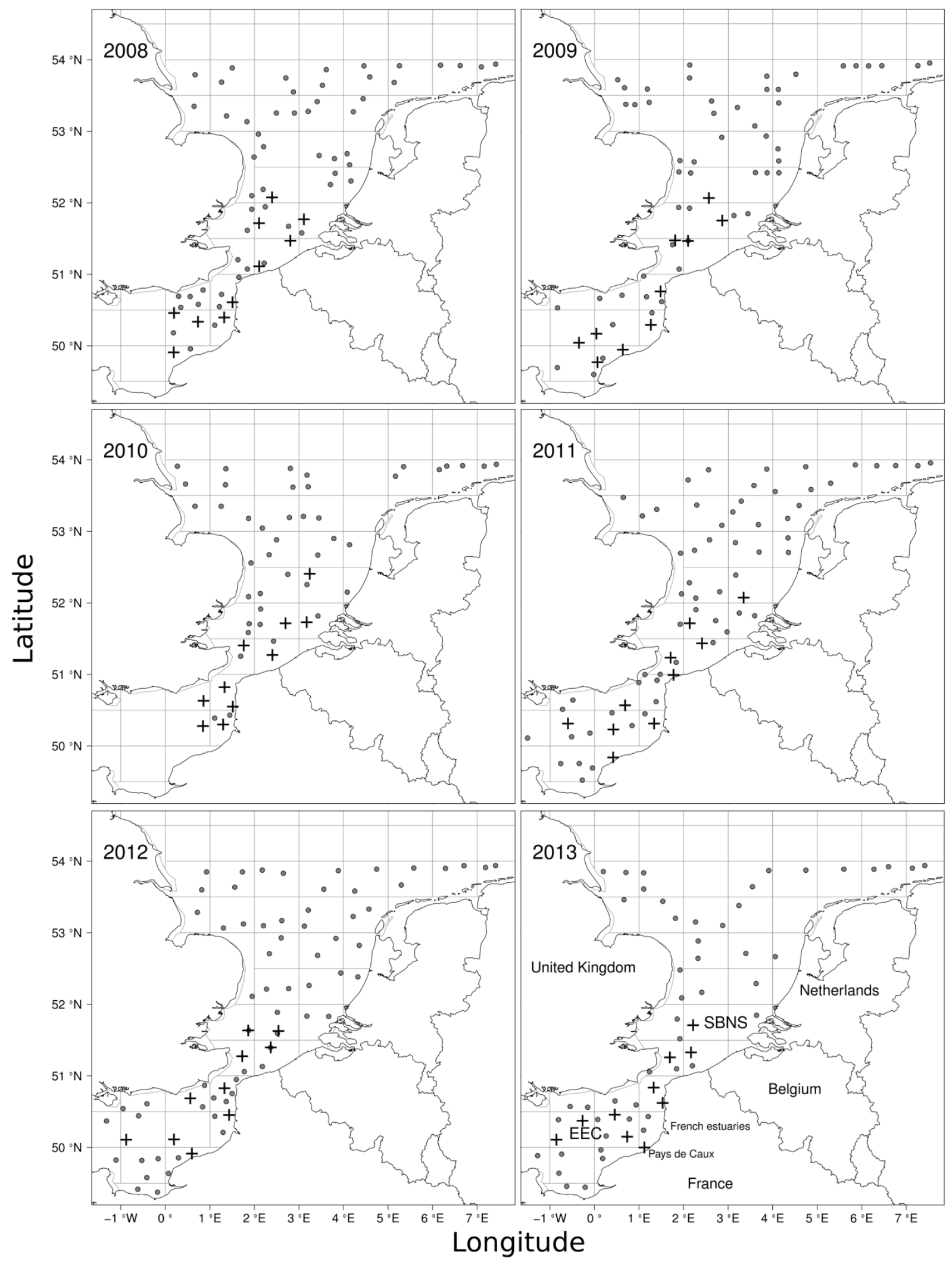


Fig. 1: Sampling locations (dots) of protist, mesozooplankton and herring larvae during the first quarter (January-February) of the French part of the IBTS from 2008-2013. Stations where larval guts were analysed (crosses), main locations used in the text and ICES statistical rectangles are also indicated.

Sea surface temperature $\left({ }^{\circ} \mathrm{C}\right)$ and salinity were continuously measured at 3-5 m below the sea surface using a thermo-salinometer. Seawater samples were collected at $1 \mathrm{~m}$ depth using a 5L Niskin bottle. Two replicates of 500 to $1000 \mathrm{ml}$ seawater were immediately filtered on glass-fibre filters (Whatman GF/F) and frozen at $-20^{\circ} \mathrm{C}$. Protists were also collected at $1 \mathrm{~m}$ below the surface using a 5L Niskin bottle and preserved in a Lugol acid solution (4\% final concentration). Mesozooplankton was collected through vertical hauls using a WP2 net (200 $\mu \mathrm{m}$ mesh size). Samples were preserved in a $0.9 \%$ buffered formalin seawater solution (Lelievre et al., 2010). Herring larvae were sampled during the night using a Mid-water Ring Net of $13 \mathrm{~m}$ long, $2 \mathrm{~m}$ diameter and $1.6 \mathrm{~mm}$ mesh size except for the last metre which has a mesh size of $500 \mu \mathrm{m}$ (ICES, 2015). The net was deployed in a double-oblique tow up to $5 \mathrm{~m}$ above the ground for at least $10 \mathrm{~min}$. Samples were immediately fixed in the formalin seawater solution.

\subsection{Samples analysis}

In-situ chlorophyll $a(\operatorname{chl} a)$ and phaeopigments concentrations were determined using the fluorescence method of Strickland and Parsons (1972). Extraction was carried out for 12h at $4^{\circ} \mathrm{C}$ in a $90 \%$ acetone solution. After centrifugation, total chla pigment concentration (in-situ chl $a$ and phaeopigments concentrations; $\mu \mathrm{g}^{-1}$ ) was measured before and after acidification with a $10 \% \mathrm{HCl}$ solution using a Trilogy Laboratory Fluorometer (Turner Designs EPA 445) calculated according to Lorenzen (1967).

Protist samples from 2008 to 2010 were analysed using an inverted microscope Utermöhl (1958). The number of cells for each species (or taxon) was counted in a sedimentation chamber and the data obtained were then recoded in term of presence-absence. Samples 
from 2011 to 2013 were analysed using SEM (LEO 438VP; modified from Paerl and Shimp, 1973). For each sample, $30 \mathrm{ml}$ were filtered on a $0.4 \mu \mathrm{m}$ polycarbonate filter deposited on a carbon tape glued to a metal stub of $10 \mathrm{~mm}$ diameter. Stubs were dried during $24 \mathrm{~h}$ under a laminar flow hood and metallized with a thin gold-palladium layer (Polaron SC7620). For each sample, the stub was totally scanned at a magnification of 3.4 $\times 4.6 \mathrm{~mm}$ and all visible species were identified. The stub was then partially scanned (one horizontal line and one vertical through the middle of the stub) at a magnification of 0.456 $\times 0.306 \mathrm{~mm}$ in order to identify very small species (Vallet et al., 2011). Each species identified was determined as present or absent. Taxonomic data obtained with SEM were finally aggregated to the same level as the one obtained from inverted microscopy so that the data are comparable between the two periods.

Mesozooplanktonic samples were processed using the Zooscan system (Gorsky et al., 2010; Grosjean et al., 2004). Prior to scanning, samples were split into two size fractions (200-500 $\mu \mathrm{m}$ and $>500 \mu \mathrm{m})$. Each fraction was subsampled using a Motoda box (Motoda, 1959). The two fractions were then scanned separately and the different objects were extracted as numerical vignettes using the ZooProcess software (Gorsky et al., 2010). The obtained vignettes were sorted automatically into different taxonomic groups, previously defined by an expert, using the random forest method available in the Plankton identifier software (Gasparini, 2007; Gorsky et al., 2010). Sorting was validated by an expert. The two size fractions were then merged to obtain the abundance of each species in the whole sample. Abundances were finally reclassified in terms of presence-absence.

Herring larvae were identified and sorted according to Russell (1976). Samples with high number of herring larvae were subsampled using a Motoda box. Herring larvae were counted and measured at their standard length to the lowest millimetre. Lengths were then 
corrected following Fox, (1996) to account for shrinkage due to preservation in formalin. Counts were raised to the total sample and expressed in number of individuals per $5000 \mathrm{~m}^{3}$.

\subsection{Larvae diet analysis}

\subsubsection{Dissection and observation of gut contents}

Larvae smaller than $20 \mathrm{~mm}$ and located south of $54^{\circ} \mathrm{N}$ were analysed as they were assumed to belong to the Downs herring component (ICES, 2015). Gut content analysis was performed according to Vallet et al. (2011). Each year, five larvae per station on a total of ten stations (Fig. 1) were analysed. Guts were removed and opened in Milli-Q water (Millipore) under a stereomicroscope. Larger prey were identified under a stereomicroscope. Gut contents were then filtered on a $0.4 \mu \mathrm{m}$ polycarbonate filter deposited on a carbon tape glued to a metal stub of $10 \mathrm{~mm}$ diameter. Stubs were dried during $24 \mathrm{~h}$ under a laminar flow hood and metallized with a thin gold-palladium layer.

Prey were identified following the same methodology as the one used for protists samples in 2011-2013. For each larvae, the stub was totally scanned at a magnification of $3.4 \times 4.6$ $\mathrm{mm}$ and partially scanned (one horizontal line and one vertical through the middle of the stub) at a magnification of $0.456 \times 0.306 \mathrm{~mm}$. All species were identified as presentabsent. Prey diameter and/or width were finally measured using an image analyzer (LEO 32). For the rest of the study, only larval sizes with at least 5 larvae analysed were kept, which corresponds to $8-15 \mathrm{~mm}$ larvae.

\subsubsection{Vacuity rate}

The vacuity rate was used an index of feeding intensity based on the number of larvae with empty gut. Larval vacuity rate (V; Berg, 1979) was calculated by station as the percentage 
of larvae at each station without any prey in their gut and by larval length as the percentage of larvae at each larval length group without any prey in their gut (Eq. 1).

$$
\mathrm{V}_{\mathrm{s}}=\mathrm{n}_{\mathrm{s}} / \mathrm{N}_{\mathrm{s}} \times 100
$$

where $V_{s}$ is the vacuity rate, $n_{s}$ is the number of larvae without prey in the gut by station or larval length and $\mathrm{N}_{\mathrm{s}}$ is the total number of larvae analysed by station or larval length.

\subsubsection{Feeding strategy}

Larval feeding strategy was determined based on the modified Costello graphical method (Amundsen et al., 1996) using the specific abundance $(\mathrm{P})$ and occurrence $(\mathrm{F})$ of the different prey.

The calculation of specific abundance $(\mathrm{P})$ was adapted to presence-absence data by Vallet et al. (2011) following Eq.2:

$$
\mathrm{P}_{\mathrm{i}}=\mathrm{n}_{\mathrm{i}} / \mathrm{N}_{\mathrm{i}} \times 100
$$

where $P_{i}$ is the specific abundance of prey $i, n_{i}$ is the number of guts where the prey $i$ was present and $\mathrm{N}_{\mathrm{i}}$ is the total number of prey within all the guts containing prey $\mathrm{i}$.

Occurrence $(\mathrm{F})$ was calculated for each year following Eq.3:

$$
\mathrm{F}_{\mathrm{i}}=\mathrm{n}_{\mathrm{i}} / \mathrm{N}_{\mathrm{f}}
$$

where $F_{i}$ is the occurrence of prey $i, n_{i}$ is the number of guts where the prey $i$ was present and $\mathrm{N}_{\mathrm{f}}$ is the total number of larvae containing prey in the guts. 
The diagram of the mean specific abundance versus the mean occurrence for the 20082013 period was then plotted and the size of the trophic niche was interpreted following Amundsen et al. (1996).

\subsubsection{Feeding selectivity}

Larval feeding selectivity was determined for each prey found in the larval guts using the modified Ivlev's Electivity Index (D; Jacobs, 1974) and adapted to presence-absence data by Vallet et al. (2011). It is based on the proportion of prey in the guts (r) and in the water (p) and was calculated following Eq.4:

$$
D_{i}=r_{i}-p_{i} / r_{i}+p_{i}-2 r_{i} p_{i}
$$

where $r_{i}$ is the ratio of prey $i$ (actually 1 ) over the total number of prey in the gut and $p_{i}$ is the ratio of prey i (actually 1) over the total number of prey in the water. It was calculated by station, then averaged by year and finally averaged overall the years.

The selectivity index varies from -1 to 0 for a negative selectivity and from 0 to 1 for a positive selectivity.

The selectivity index was plotted according to the occurrence $\left(\mathrm{O}_{\mathrm{i}}\right)$ of prey in the water for years 2008-2013 calculated following Eq. 5:

$$
\mathrm{O}_{\mathrm{i}}=\mathrm{n}_{\mathrm{i}} / \mathrm{N}_{\mathrm{f}} \times 100
$$

where $n_{i}$ is the number of station where the prey $i$ was present and $N_{f}$ is the total number of station analysed. 


\subsection{Mapping}

The spatial distribution of Downs herring larvae were mapped by length class for each year using the R software (R Development Core Team 2005). Hydro-biological parameters and the abundance of mesozooplankton were also mapped for each year, using the kriging interpolation method (Legendre and Legendre, 2012) of the gstat (Pebesma, 2004) package of the R software.

\subsection{Statistical analyses}

A correspondence analysis (CA) was performed on the occurrence of the different prey found in the larval guts for all years between 2008 and 2013 to study how the diet composition varied according to the larval size and across the years. Larval lengths were used as the descriptors (columns, $n=14$ ) and prey were used as the objects (rows, $n=38$ ). The CA was performed using the FactoMineR package (Lê et al., 2008) of the R software.

\section{Results}

\subsection{Hydro-biological parameters and mesozooplankton distribution}

Between 2008 and 2013, the spatial distribution of sea surface temperature, salinity, total chla pigment concentrations and total abundance of mesozooplankton were highly structured in the EEC and SBNS (Fig. 2). Sea surface temperature and salinity depicted a coastal-offshore gradient with higher values (between $8-11^{\circ} \mathrm{C}$ and $33-35.5$, respectively) in the middle of the EEC and SBNS. Conversely, high concentrations of total chla pigment (between 2-6 $\mu \mathrm{g} \mathrm{l}^{-1}$ ) were located along the French and Belgium coasts in the EEC and SBNS. Abundance of mesozooplankton showed higher values (between 25000-47800 ind $\mathrm{m}^{-3}$ ) along the three French estuaries (Somme, Authie and Canche) and in front of the Belgium frontier. 
Sea surface temperature was higher in 2008 and 2012-2013 (from 7-11 ${ }^{\circ} \mathrm{C}$ ) and lower in 2009-2011 (from $4-10^{\circ}$ C). Salinity was higher in 2009-2013 (from 30-35.5) compared to 2008 (from 28-34.6). Total chla pigment concentrations were higher in 2008-2009 and 2011-2012 (from 990-47730 ind $\mathrm{m}^{-3}$ ) and lower in 2010 and 2013 (from 2-30980 ind $\mathrm{m}^{-3}$ ). Total abundance of mesozooplankton was higher in 2008-2010 (from 0.2-6 $\mu \mathrm{g} \mathrm{l}^{-1}$ ) compared to 2011-2013 (from 0.1-5.8 $\mu \mathrm{g} \mathrm{l}^{-1}$ ). 


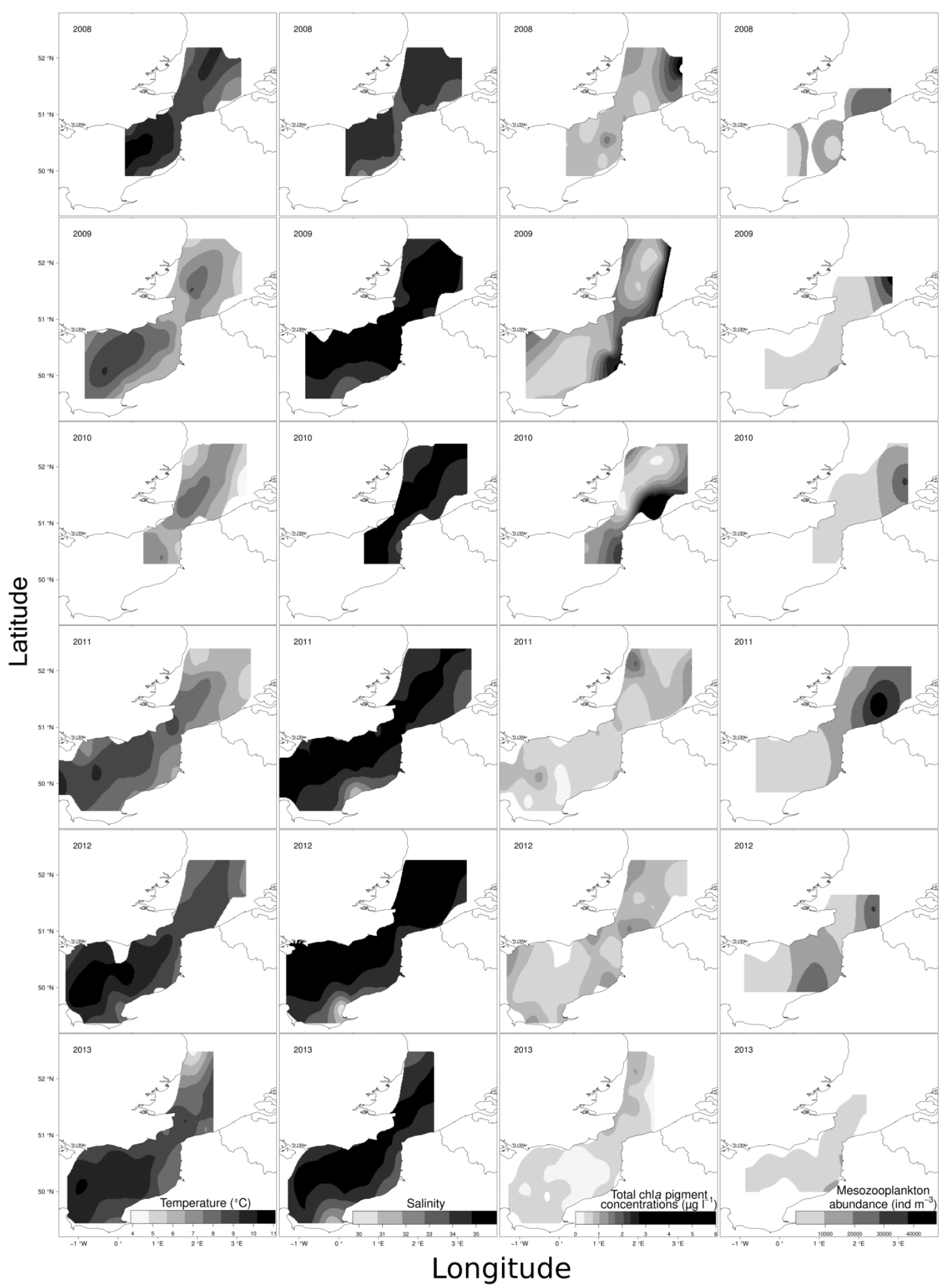

Fig. 2: Spatial distribution of hydro-biological parameters (sea surface temperature, salinity and total chla concentrations) and total abundance of mesozooplankton during winter (January-February) in the EEC and SBNS from 2008-2013. 


\subsection{Larval distribution}

Downs herring larvae showed a clear southwest-northeast gradient in their spatial distribution with an increase in their larval size and a decrease in their abundance (Fig. 3). Highest abundance was located mainly along the three French estuaries and in the middle of the EEC. Smaller larvae $(7-12 \mathrm{~mm})$ were mainly located in the EEC and larger larvae $(13-20 \mathrm{~mm})$ in the SBNS. 


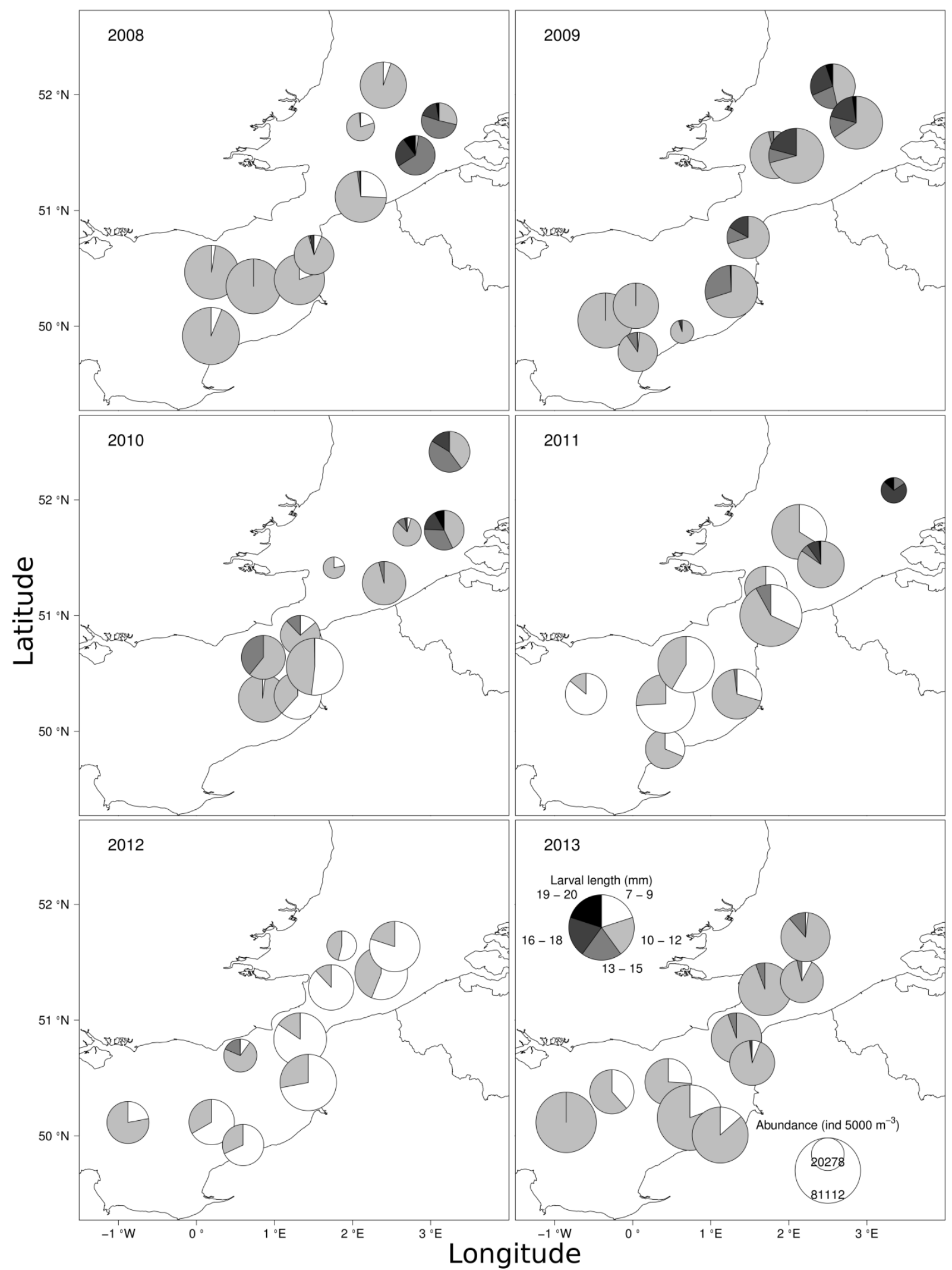

Fig. 3: Spatial distribution of Downs herring larvae abundance (log-transformed) according to their length (mm) during winter (January-February) in the EEC and SBNS from 2008-2013. Pie size is related to the total larval abundance observed at each station. Only stations where larval guts have been analysed are shown. 


\subsection{Vacuity rate}

Of the 283 larvae analysed, $45 \%$ were empty. The vacuity rate varied according to larval size (Fig. 4). The highest values were observed for larvae of 8 and $13 \mathrm{~mm}$ (respectively 74 and $56 \%)$. For the other sizes, the vacuity rate was almost constant under $50 \%$.

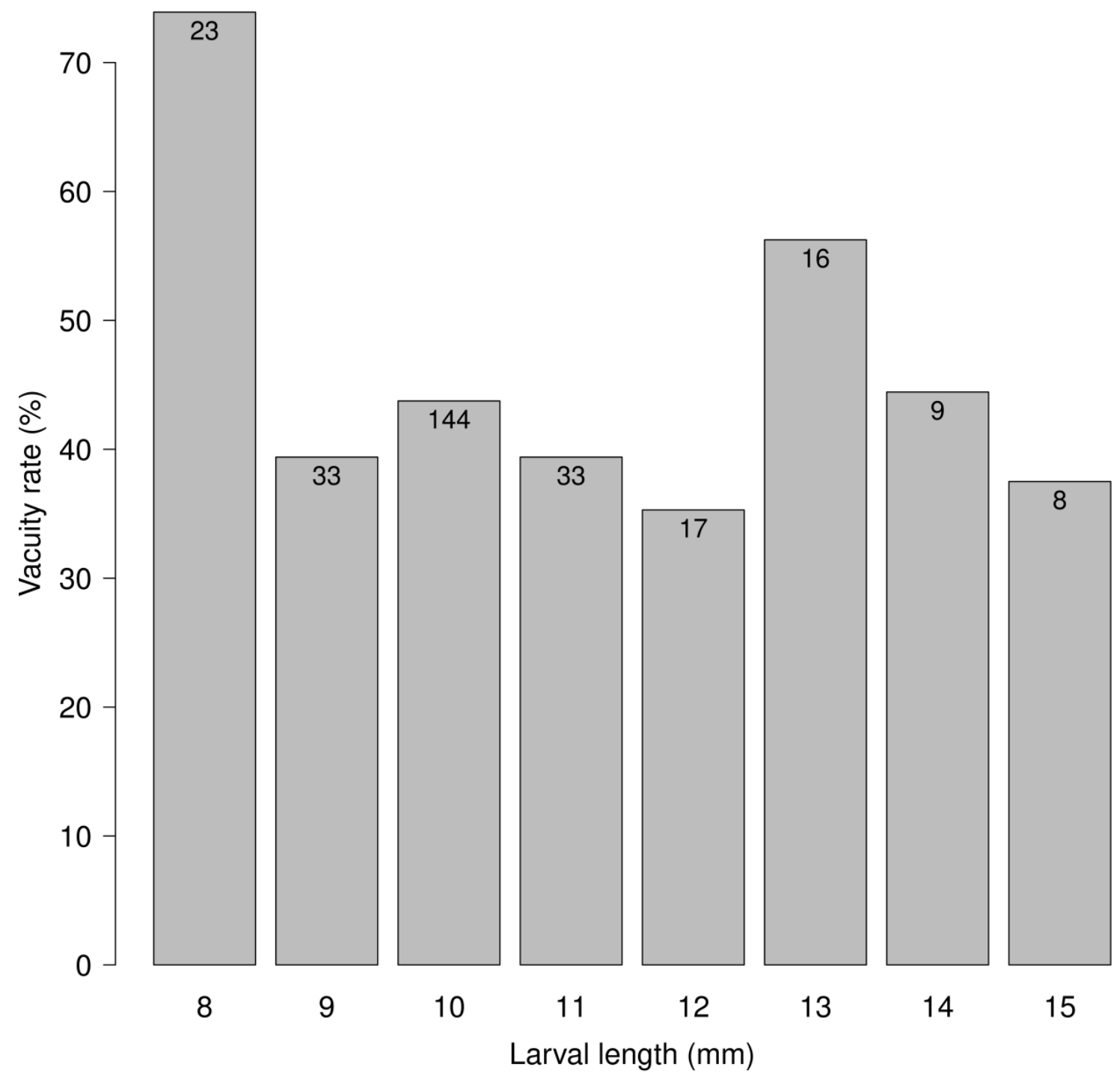

Fig. 4: Vacuity rate (\%) for Downs herring larvae between 8 and $15 \mathrm{~mm}$ during winter (January-February) in the ECC and SBNS from 2008-2013. Number of larvae analysed for each length is also indicated.

The vacuity rate also varied in time and space (Fig. 5). It was higher in 2008, 2009 and $2011(54-66 \%)$ compared to the other years $(20-44 \%)$. Three areas of low vacuity rate 
were identified along the three French estuaries, in the middle of the EEC and the Dover Strait (except for 2011). The larvae analysed in these areas also had a higher diversity of prey in their gut contents (Fig. 5) compared to the other areas. 


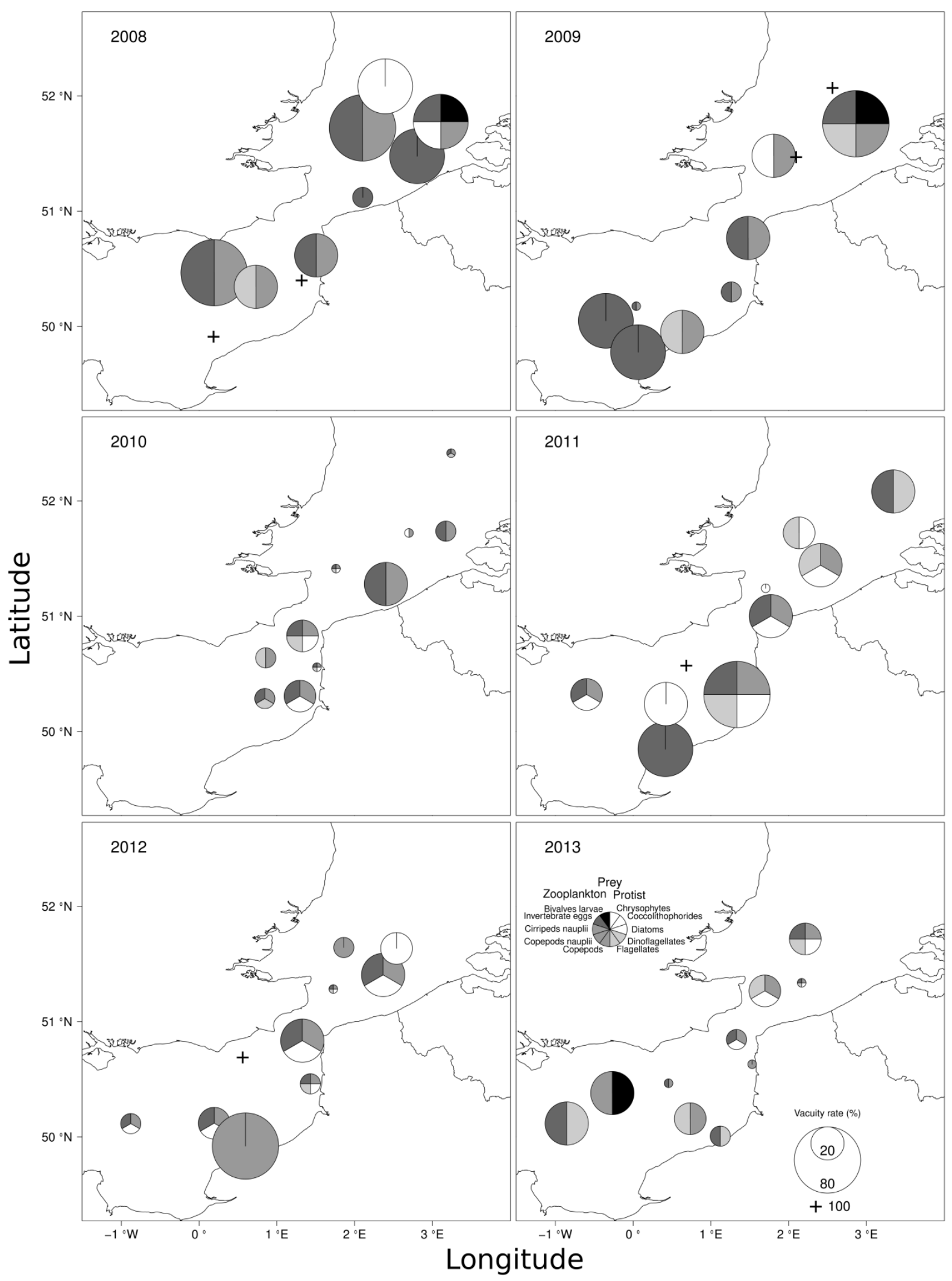

Fig. 5: Spatial distribution of prey composition in the larval guts and vacuity rate (\%) of Downs herring larvae from 8 to $15 \mathrm{~mm}$ during winter (January-February) in the EEC and SBNS from 2008-2013. Pies represent the prey composition and pie size is related to the vacuity rate at each station. Details on each prey group are given in Table 1. 


\subsection{Feeding strategy}

Of the 38 prey taxa identified in the gut contents, 27 were protist (auto- and heterotroph unicellular organisms) and 11 were zooplanktonic (Table 1). $31 \%$ of the larvae analysed ingested exclusively zooplanktonic prey, $11 \%$ ingested protist prey and 58\% ingested both.

Prey size varied from 3 to $450 \mu \mathrm{m}$ (Table 1) with the largest sizes for the zooplanktonic prey $(8-450 \mu \mathrm{m})$ and conversely for protist prey $(3-145 \mu \mathrm{m})$.

Table 1: Prey composition observed in the guts of Downs herring larvae between 8-15 mm during winter (January-February) in the EEC and SBNS from 2008-2013. Prey size $(\mu \mathrm{m})$, mean $( \pm$ SD) values of prey occurrence $(F)$, specific-abundance $(P)$ and selectivity $(D)$ are also indicated.

\begin{tabular}{|c|c|c|c|c|c|c|c|}
\hline & Groups & Prey taxa & Abbrevations & Size (min-max) & $F(\%)$ & $P(\%)$ & $D$ \\
\hline & Chrysophytes & & Chry & 9.3 & $1 \pm 2.4$ & $16.7 \pm 40.8$ & - \\
\hline & Coccolithophorides & & Cocc & 9.4 & $0.5 \pm 1.1$ & $16.7 \pm 40.8$ & - \\
\hline & Diatoms & Chaetoceros spp. & Chae & 10 & $2 \pm 4.8$ & $5.6 \pm 13.6$ & $-0.06 \pm 0$ \\
\hline & & Corethron criophilum & C.cri & 20 & $0.6 \pm 1.5$ & $16.7 \pm 40.8$ & - \\
\hline & & Coscinodiscus spp. & Cosc & $120-144$ & $2 \pm 2.4$ & $28.3 \pm 40.2$ & $0,33 \pm 0.08$ \\
\hline & & Delphineis surirella & D.su & $3.7-4.8$ & $2.8 \pm 3.8$ & $30.6 \pm 40$ & - \\
\hline & & Minidiscus trioculatus & M.tri & $3-4.8$ & $2.3 \pm 1.9$ & $22.2 \pm 19.5$ & $0.16 \pm 0.15$ \\
\hline & & Navicula spp. & Navi & $2.7-6.6$ & $4.1 \pm 4.3$ & $30.8 \pm 37.2$ & $0.1 \pm 0.41$ \\
\hline & & Nitzschia spp. & Nitz & $5-5.2$ & $1.4 \pm 2.2$ & $13.9 \pm 22.2$ & $-0.43 \pm 0.03$ \\
\hline & & Plagiogrammopsis vanheurckii & P.van & $8-25$ & $1 \pm 1.6$ & $16.7 \pm 25.8$ & $0.38 \pm 0.25$ \\
\hline & & Plagiotropis spp. & Plag & 3.8 & $1 \pm 2.4$ & $8.3 \pm 20.4$ & $0.39 \pm 0$ \\
\hline & & Psammodictyon panduriforme & P.pan & 4.9-13.9 & $6.9 \pm 5.7$ & $40.6 \pm 26.8$ & $0.23 \pm 0.42$ \\
\hline & & Raphoneis amphiceros & R.amp & $45-120$ & $1.6 \pm 3.9$ & $4.8 \pm 11.7$ & - \\
\hline \multirow[t]{19}{*}{ Protist } & & Thalassiosira curviseriata & T.cur & $3.9-6$ & $3.3 \pm 3$ & $43.3 \pm 38.3$ & $0.51 \pm 0.27$ \\
\hline & & Thalassiosira spp. & Thal & $15.32-31.4$ & $1.2 \pm 2$ & $13.9 \pm 22.2$ & $-0.25 \pm 0.14$ \\
\hline & & Thalassiosira tenera & T.ten & $6.5-8.4$ & $2.4 \pm 4.7$ & $20.8 \pm 40.1$ & $-0.33 \pm 0.12$ \\
\hline & & Thalassiosira levedenri & T.lev & 10.9-15.9 & $1.5 \pm 2.4$ & $25 \pm 41.8$ & - \\
\hline & & Unidentified diatoms & Dia.un & 20 & $0.7 \pm 1.8$ & $16.7 \pm 40.8$ & - \\
\hline & Dinoflagellates & Alexandrium spp. & Alex & $50-60$ & $2.9 \pm 7.1$ & $4.2 \pm 10.2$ & - \\
\hline & & Dinophysis acuminata & D.acu & $57.47-100$ & $7 \pm 10.4$ & $38.5 \pm 37.8$ & - \\
\hline & & Diplopsalis spp. & Dipl & $66.02-130.7$ & $1.7 \pm 3$ & $8.7 \pm 13.5$ & - \\
\hline & & Gonyaulax spp. & Gony & $65-127$ & $5.6 \pm 7.1$ & $16.8 \pm 18.8$ & $0.99 \pm 0.01$ \\
\hline & & Prorocentrum lima & P.lim & $4.5-10$ & $1 \pm 1.6$ & $22.2 \pm 40.4$ & $0.6 \pm 0$ \\
\hline & & Prorocentrum micans & P.mic & $30.31-48.99$ & $3.9 \pm 5.1$ & $18.3 \pm 22.3$ & $0.74 \pm 0.08$ \\
\hline & & Pyrophacus spp. & Pyro & 66.49 & $1 \pm 2.4$ & $2.1 \pm 5.1$ & $0.97 \pm 0$ \\
\hline & & Unidentified dinoflagellates & Din.un & 145 & $0.5 \pm 1.1$ & $16.7 \pm 40.8$ & - \\
\hline & Flagellates & & Flag & 4.5 & $0.4 \pm 1$ & $8.3 \pm 20.4$ & - \\
\hline & Copepods & Euterpina acutifrons & E.acu & $135-210$ & $7.9 \pm 5.5$ & $42.1 \pm 28.3$ & $0.16 \pm 0.35$ \\
\hline & & Oncaea spp. & Onca & $74-350$ & $7.5 \pm 8.6$ & $33.3 \pm 27.9$ & $0.47 \pm 0.39$ \\
\hline & & Paracalanus parvus & P.par & $100-400$ & $22.7 \pm 16.9$ & $51.3 \pm 10.2$ & $0.43 \pm 0.27$ \\
\hline & & Pseudocalanus elongatus & P.elo & $106-370$ & $4 \pm 2.1$ & $69.4 \pm 40$ & $-0.18 \pm 0.19$ \\
\hline & & Temora longicornis & T.lon & $108-450$ & $2.8 \pm 4.2$ & $29.2 \pm 40.1$ & $-0.01 \pm 0.54$ \\
\hline \multirow[t]{6}{*}{ Zooplankton } & & Unidentified calanoides & Cal.un & 148-199 & $2.3 \pm 3.2$ & $29.4 \pm 39.4$ & $-0.21 \pm 0.22$ \\
\hline & & Unidentified copepods & Cop.un & $210-229$ & $1.9 \pm 2.3$ & $33.3 \pm 40.8$ & - \\
\hline & Copepods nauplii & & Cop.n & $60-224.3$ & $20.4 \pm 14.9$ & $40.5 \pm 9.3$ & $0.71 \pm 0.11$ \\
\hline & Cirripeds nauplii & & Cir.n & $60-150$ & $7.6 \pm 8.1$ & $46.4 \pm 29.1$ & $0.63 \pm 0.25$ \\
\hline & Invertebrate eggs & & Eggs & $7.8-163$ & $34.9 \pm 16.1$ & $53.9 \pm 16$ & $0.92 \pm 0.05$ \\
\hline & Bivalve larvae & & Biv.I & $96.24-230$ & $1.7 \pm 2$ & $25 \pm 38.7$ & $0.27 \pm 0.04$ \\
\hline
\end{tabular}

Plot of specific-abundance versus prey occurrence showed a large trophic niche indicating that different prey types were consumed (Fig. 6). A high inter-individual variability in the 
diets (occurrences were very low and specific abundances very variable) was also observed. Except for several prey like Pseudocalanus elongatus, invertebrate eggs and Paracalanus parvus, it appeared that there was no dominant prey and that Downs herring larvae were mostly generalist feeders. Zooplanktonic prey had on average higher specificabundance and prey occurrence compared to protist prey. Among the zooplanktonic prey, the copepods $P$. elongatus and $P$. parvus and invertebrate eggs had the highest specificabundance, respectively $69 \pm 40 \%, 51 \pm 10 \%$ and $54 \pm 16 \%$ (Table 1). P. parvus and invertebrate eggs also had the highest occurrence $(0.23 \pm 0.17-0.35 \pm 0.16)$ whereas $P$. elongatus had a low one $(0.04 \pm 0.02)$. Nauplii of copepods and cirripeds as well as the copepod Euterpina acutifrons had specific-abundance of $40 \pm 9 \%, 46 \pm 29 \%$ and $42 \pm$ $28 \%$, respectively and nauplii of copepods had an occurrence around $0.20 \pm 0.15$. Other zooplanktonic prey had specific-abundance lower than $33 \%$ and low occurrence $(<0.08)$. Among the protist prey, Thalassiosira curviseriata, Psammodictyon panduriforme and Dinophysis acuminata had the highest specific-abundance but relatively low occurrence $(<0.07)$. Other protist prey had low specific-abundance $(<35 \%)$ and occurrence $(<0.04)$. 


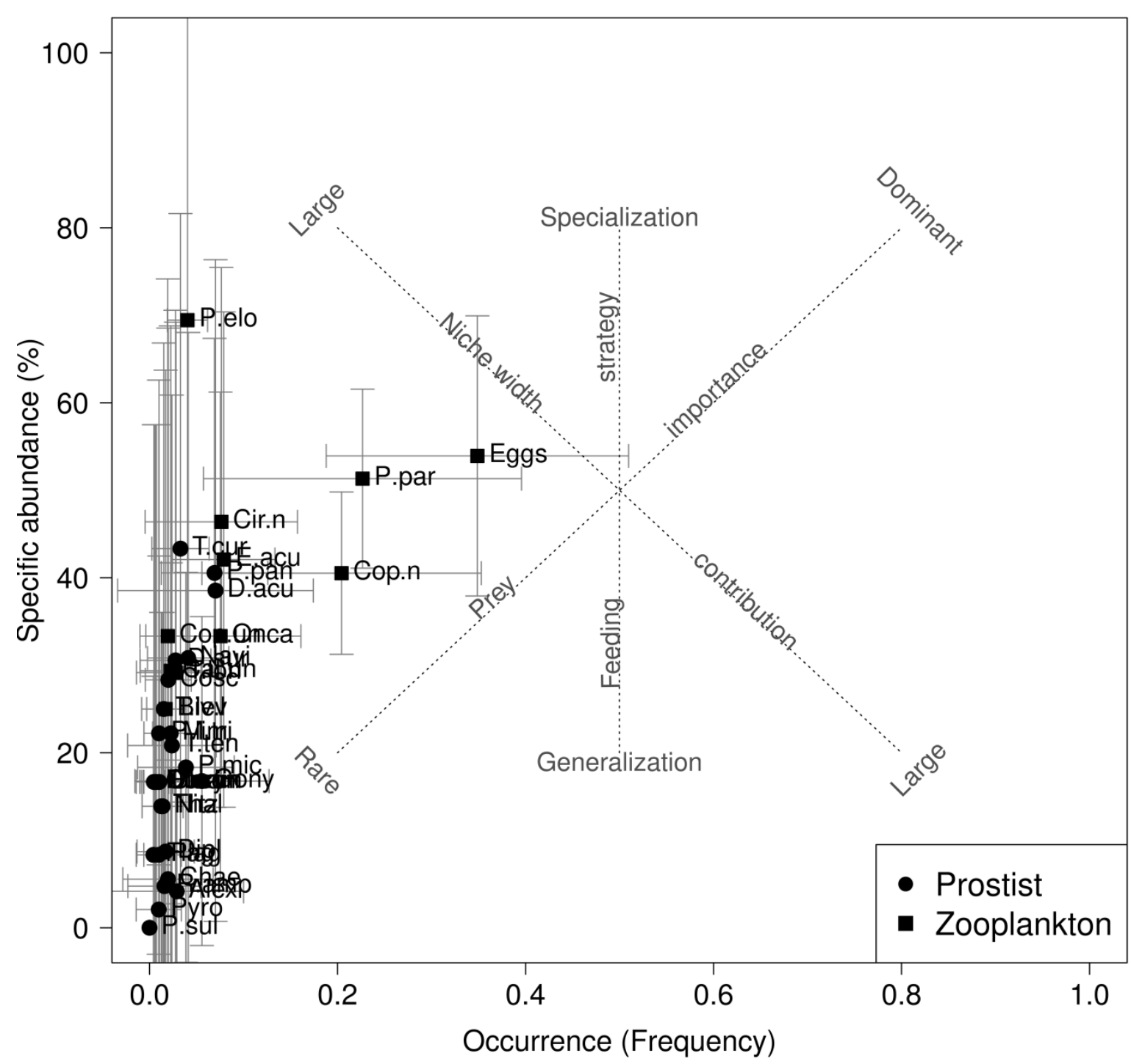

Fig. 6: Feeding strategy of Downs herring larvae between 8 and $15 \mathrm{~mm}$ during winter (January-February) in the EEC and SBNS from 2008-2013. Specific-abundance and occurrence of each prey observed in the larval guts are plotted as their mean $( \pm \mathrm{SD})$ for the 2008-2013 period. See Table 1 for the prey abbreviations.

Results of the CA showed that the diet composition varied with larval length (Fig. 7). The first and second axes of the CA explained respectively $32.64 \%$ and $21.87 \%$ of the total variability. The first axis clearly separated three groups of larval sizes: larvae of 8-12 mm, larvae of $13 \mathrm{~mm}$ and larvae of $14-15 \mathrm{~mm}$. On the second axis, larvae of $13 \mathrm{~mm}$ were clearly separated from other larvae. These three groups of larvae were associated with different prey. Smaller larvae $(8-12 \mathrm{~mm})$ were close to a large number of small prey including 
protist like diatoms (Coscinodiscus spp., Thalassiosira spp., Raphoneis amphiceros, Plagiotropis spp. and Delphineis surirella), dinoflagellates (Pyrophacus spp., Prorocentrum micans, Alexandrium spp., Dinophysis spp., Diplopsalis spp., Prorocentrum lima) and zooplanktonic prey including invertebrate eggs, E. acutifrons, nauplii of cirripeds and copepods and bivalve larvae. Larger larvae $(13-15 \mathrm{~mm})$ were associated with a lower number of prey. Larvae of $13 \mathrm{~mm}$ were close to unidentified calanoids, Oncaea spp., chrysophytes and diatoms whereas larvae of 14-15 mm were close to larger copepods prey including Temora longicornis, P. parvus, unidentified copepods, P. elongatus (106$370 \mu \mathrm{m})$ but also small protists like the dinoflagellate Gonyaulax spp. and the diatom $T$. curviseriata. 


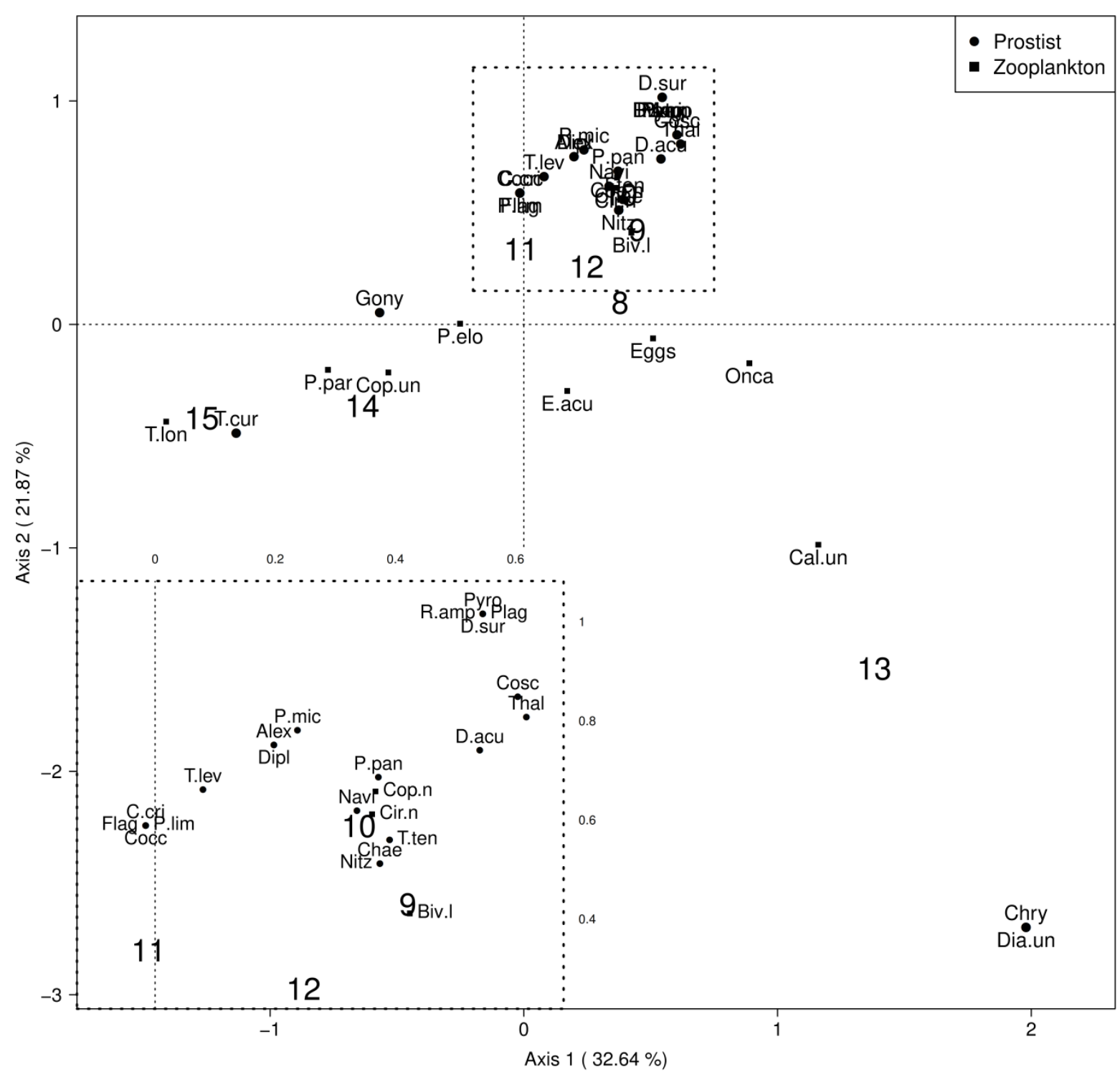

Fig. 7: Plot of the first two axes of the CA performed on prey composition in the guts of larval herring from 8 to $15 \mathrm{~mm}$ during winter (January-February) in the EEC and SBNS from 2008-2013. The insert in the bottomleft corner zooms on the larvae of 9-12 $\mathrm{mm}$. See Table 1 for the prey abbreviations.

Among the 38 prey taxa identified in the guts, 25 were also found in the water (protist and mesozooplankton) samples. Hence, the selectivity was calculated only for these 25 taxa (see Table 1.). The selectivity index $(D)$ showed that except for P. parvus and for the nauplii of copepods, there was an inverse relationship between prey selectivity and prey occurrence in the water. Highly selected prey (>0.5) were Gonyaulax spp. $(0.99 \pm 0.01$; Table 1), Pyrophacus spp. (0.97), invertebrate eggs $(0.92 \pm 0.05)$, P. micans $(0.74 \pm 0.08)$, 
nauplii of copepods $(0.71 \pm 0.11), P$. lima $(0.60)$, Oncaea spp. $(0.47 \pm 0.39)$ and $T$. curviseriata $(0.51 \pm 0.27)$ and conversely for Nitzschia spp. (-0.43 \pm 0.03$)$, Thalassiosira tenera $(-0.33 \pm 0.12)$, Thalassiosira spp. $(-0.25 \pm 0.14)$, unidentified calanoid $(-0.21 \pm$ $0.21)$ and P. elongatus $(-0.18 \pm 0.19 ;$ Fig. 8$)$. The selectivity index of prey varied between 2008 and 2013 mainly for prey like T. longicornis $(-0.01 \pm 0.54), P$. panduriformis $(0.23 \pm$ 0.54), Navicula spp. $(0.10 \pm 0.41)$, Oncaea spp. $(0.47 \pm 0.39)$ and E. acutifrons $(0.16 \pm$ $0.35)$.

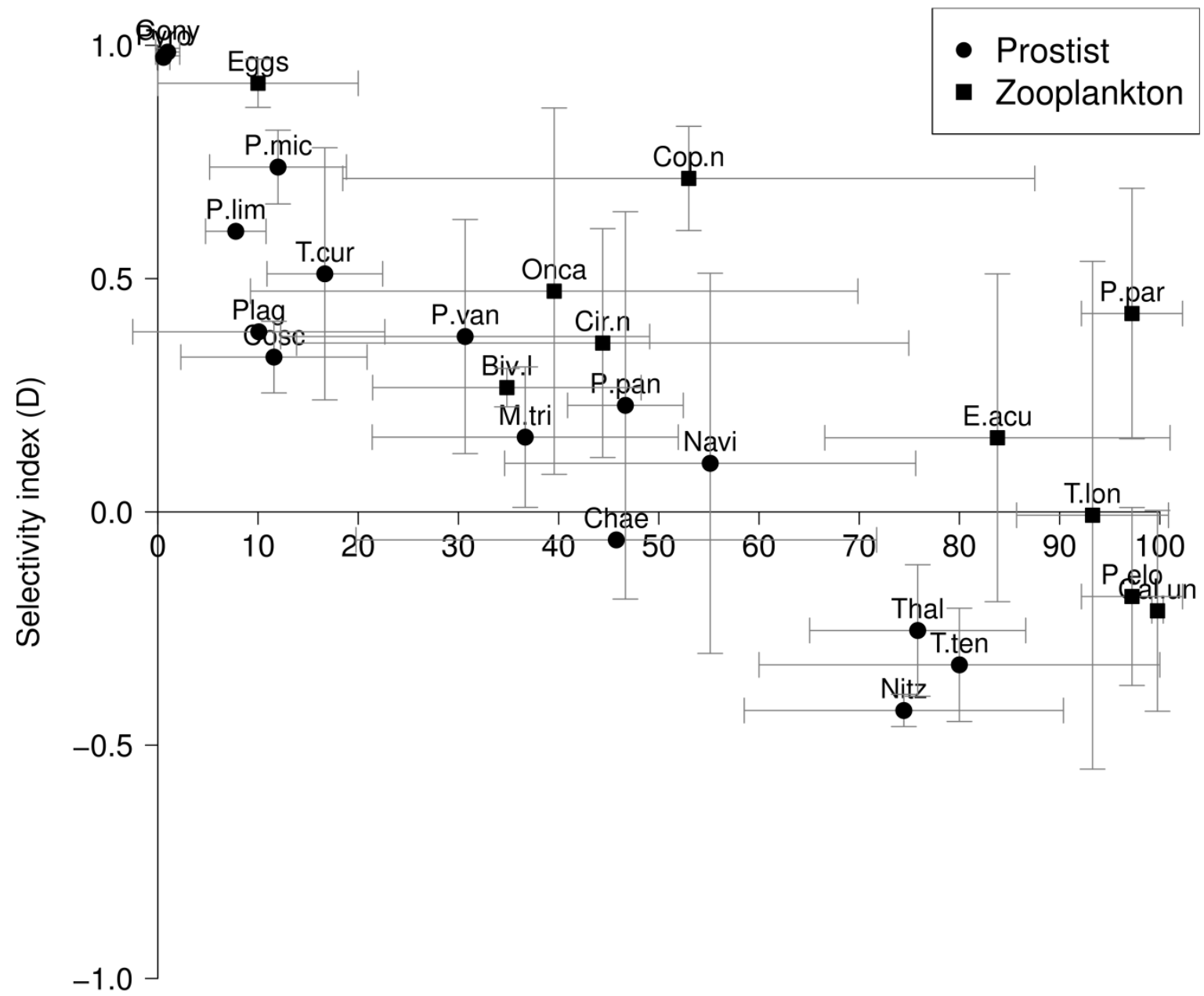

Occurrence (\%) 
Fig. 8: Selectivity and occurrence in the water of prey consumed by Downs herring larvae of 8 to $15 \mathrm{~mm}$ during winter (January-February) in the EEC and SBNS from 2008-2013. Selectivity and occurrence are plotted as their mean $( \pm$ SD) for the 2008-2013 periods. See Table 1 for the prey abbreviations.

\section{Discussion}

Several methodological aspects have been raised by the present study, in particular on the use of gut contents analysis and SEM to study the diet of larval fish. These points need to be debated before discussing the highlights brought by our study on the larval feeding of Downs herring.

\section{Relevance of gut contents to depict larval fish diet}

Gut contents analysis is by far the most used approach to study the feeding behaviour of marine organisms (Hyslop, 1980) because it is a direct approach and an easy way to quickly assess the different prey ingested by a predator. However, several factors may affect their relevance to depict larval fish diet. Many authors stressed the potential underestimation of larval feeding (de Figueiredo et al., 2005; Pepin and Dower, 2007; Theilacker et al., 1996) due to the evacuation of gut contents during larval capture or fixation (Bjørke, 1976; Checkley, 1982; Dower et al., 1998; Hay, 1981; Lebour, 1924). Night sampling may also lead to some bias because larval feeding decreases with light intensity at nightfall (Haslob et al., 2009; Munk et al., 1989) and has a peak just after sunrise (Bjørke, 1976; Blaxter, 1965; Heath, 1993) and before sunset (Cohen and Lough, 1983; Fox et al., 1999). These two phenomenon may have some implications in the estimation of the evacuation rate which highly relies on the observed number of empty larvae. In our case, as the larval sampling extended from sunset until sunrise, some larvae could have already fed several hours before (Blaxter, 1965; Fossum and Johannessen, 1979; Pedersen, 1984). Hence, the vacuity rate obtained in the present study for Downs herring larvae is potentially overestimated and should be considered as a maximum value. 
However, since there is no reason why this overestimation should not be constant for the different larval sizes considered in the present study, the comparison of vacuity rate between these larval sizes remains relevant.

The other main criticism that is addressed to gut contents analysis is that it provides only a momentary image of the predator diet and is largely influenced by the number of larvae analysed. In our case, it is compensated by the shorter duration of the larval phase compared to juveniles and adults. We covered the whole distribution area of 8-15 mm larvae and their potential prey by sampling both in the EEC and the SBNS. Whereas the number of larvae analysed in the present study could appear as relatively low and/or insufficient, it already represents a huge amount of sampling effort. Increasing the number of larvae analysed will lead to increase the number of prey rarely ingested but will not change the picture we have of the larval diet. We then assume that the number of larvae analysed in our study was sufficient to adequately depict the diet of Downs herring larvae.

\section{Interest of SEM in larval gut contents analysis: pros and cons}

Whereas most of the studies based on gut contents analysis relied on OM (Arula et al., 2012; Blaxter, 1965; Catalán et al., 2010; Davis et al., 2012; Landaeta et al., 2014; Robert et al., 2011), recent studies by Koubbi et al. (2007), Montagnes et al. (2010) and Vallet et al. (2011) recognised that SEM had strong advantages over the other methods. They proved that $\mathrm{OM}$ led to a truncated vision of first-feeding larvae diet by ignoring the relevance of smaller protists and zooplanktonic prey. Our study confirmed the usefulness of the SEM to study the diet of small Downs herring larvae $(8-15 \mathrm{~mm})$ as a huge quantity of prey smaller than $50 \mu \mathrm{m}$ were detected. This would not have been possible with OM only. The other main advantage lies into the taxonomic accuracy SEM provides especially for protists identification. In our study, most of them were determined at the species level 
which could not have been done with inverted microscopy for instance. If one wants to calculate a selectivity index that takes into account this very high precision, determination of prey in the water should also been achieved with the same level of precision. This is not always an easy task to do, especially when dealing with small protist. In our study, we also used SEM to reach the same precision when we analysed protist samples but only for the 2011-2013 period as those from the 2008-2010 period were already analysed and discarded. This ended up with several species for which it was not possible to calculate the selectivity index, in particular those that were observed in the guts only between 2008 and 2010. For the other prey for which a selectivity was produced, the difference in the methodology of samples analysis was accounted for by decreasing the level of taxonomic determination obtained from SEM from species to genera so that it was comparable with inverted microscopy. In this way, it ended up with an unbiased selectivity index.

SEM also has several disadvantages. The first one is that it is expensive and time consuming if one wants to analyse all the stubs and identify and count all the prey. However, as stated by Baker et al. (2014), counting prey is not essential and prey abundance does not systematically bring more significant information on fish diet than prey occurrence. He argued that not only is it easier to calculate, prey occurrence is also more reliable and robust. From the several tests (not presented here) that we performed, we also reached the same kind of conclusion that the benefit in term of information on the larval diet was not enough to compensate for the time spent (up to three times more) to scan all the stub. In our study, SEM was then used in a qualitative way and prey were determined in terms of presence-absence.

The potential of SEM could be limited by the solution used to preserve the samples. While zooplankton samples are classically preserved in a formalin solution, one knows that it is not adapted to preserve soft-bodied organisms (Montagnes et al., 2010) like naked ciliates 
and non-armoured dinoflagellates. This could explain why none of these organisms had been found in the guts of the present study whereas their relevance for fish larvae had been underlined by several authors (Bjørke, 1976; Checkley, 1982; de Figueiredo et al., 2007, 2005; Fukami et al., 1999; Hunt von Herbing et al., 2001; Hunt von Herbing and Gallager, 2000; Lasker, 1975; Lebour, 1921; Nagano et al., 2000). Even if soft-bodied organisms are rapidly digested hence could be hard to detect in the gut contents (de Figueiredo et al., 2007, 2005; Fukami et al., 1999; Hunt von Herbing et al., 2001; Nagano et al., 2000; Ohman et al., 1991), their study would require to preserve the larvae in a different preservative solution like Bouin or Lugol (de Figueiredo et al., 2007, 2005).

Except for soft-bodied organisms, we assume that gut contents analysis based on SEM was a valuable way to study the feeding of Downs herring larvae.

\section{Main feeding areas}

In mid-January of the 2008-2013 period, Downs herring larvae of 8-15 mm were mainly distributed following a spatial gradient of increasing size and decreasing abundance from the EEC to the SBNS. These larvae were mainly located in areas of higher temperature and salinity and variable chlorophyll $a$ concentrations and mesozooplankton abundance. Three main areas of low vacuity rate were identified along the three French estuaries (Somme, Authie and Canche), in the Dover Strait and in the middle of the EEC. The first two areas spatially matched with high chlorophyll $a$ concentrations and high abundance of mesozooplankton. Larvae along the three French estuaries were usually smaller (8-12 mm) than those in the SBNS (13-15 mm). The third area in the middle of the EEC did not match with any particular high prey concentration and was occupied mainly by small larvae (8-12 $\mathrm{mm}$ ). Temporal variations in the larval vacuity were shown and larvae in the years 2008 , 2009 and 2011 had usually a higher vacuity rate. Since the environmental and trophic 
conditions showed little temporal variation in their spatial structure, these temporal variations in the vacuity rate still remain unexplained. This bears out that a relationship between nutrition success and environmental condition cannot always be found when analysing larval gut contents due to differences in integration time (Fox et al., 1999).

\section{Relevance of protist}

Our study clearly showed that protist constitutes a relevant part of Downs herring larvae diet both in term of diversity and positive selectivity. While this was previously observed for herring from other areas by Bjørke (1976), Checkley (1982), de Figueiredo et al. (2007, 2005) and Lebour (1921), our study provides for the first time the list of species ingested along with their selectivity for the Downs component of herring larvae.

Dinoflagellates including Alexandrium spp., Dinophysis acuminate, Prorocentrum micans, Pyrophacus spp. and Diplopsalis spp. and most of the diatoms were positively selected.

Direct or indirect consumption of protist by fish larvae is still a matter of debate (Bjørke, 1976; Checkley, 1982; de Figueiredo et al., 2007, 2005; Fukami et al., 1999; Hunt von Herbing et al., 2001; Hunt von Herbing and Gallager, 2000; Lasker, 1975; Lebour, 1921; Nagano et al., 2000). They might not be used directly by larvae for their growth as suggested by Hjelmeland et al. (1988) because their digestive tract remains incompletely developed and limit their ability to digest and absorb microalgae. However, it has been reported that ingestion of particular phytoplanktonic species like the diatoms Coscinodiscus spp. plays an essential role in the larval growth by improving the digestion efficiency of other prey like zooplankton through the increase of the enzymatic activity (Cahu et al., 1998; Hjelmeland et al., 1988; Illing et al., 2015; Reitan et al., 1997; St. John et al., 2001) and a significant contribution has an intake of lipid and free amino acids (Braven et al., 1995). 
Conversely, some diatom species like Nitzschia spp., Thalassiosira spp. and Thalassiosira tenera were clearly negatively selected whereas they were highly abundant in the water column. This might be due to their elongated form which makes them difficult to be ingested by small larvae. Our study also revealed an efficient feeding on toxic dinoflagellates like Alexandrium spp. and Gonyaulax spp., both species being associated to low fish survival and mortality (Gosselin et al., 1989; Huntley, 1989; Robineau et al., 1991).

\section{Ontogenetic dietary shift}

The correspondence analysis clearly showed that there was a shift in the diet of Downs herring larvae at a size of $13 \mathrm{~mm}$. Change in the diet was previously observed in experimental studies by Checkley (1982) to occur at a similar size (12 $\mathrm{mm})$ for the other herring populations. The diet of first feeding larvae $(8-12 \mathrm{~mm})$ was more diverse and composed of previously enumerated protist prey and small zooplanktonic prey like Euterpina acutifrons, Oncaea spp., copepodite stages of Pseudocalanus elongatus and nauplii of copepods and cirripeds. The selection of zooplankton prey by fish larvae relies on their size, their catchability, their escape capacity as well as the larval behaviour (Checkley, 1982; Heath, 1993), length and the opening of the mouth (Arula et al., 2012; Blaxter, 1965; Checkley, 1982; Cohen and Lough, 1983), positive selection of these small copepods suggests that they were more accessible, due to their more limited escape capacity and their smaller size (Checkley, 1982) and conversely for large zooplanktonic prey.

Larvae greater than $13 \mathrm{~mm}$ had a less diversified diet mainly composed of zooplanktonic prey including larger copepods like T. longicornis and Paracalanus parvus and also invertebrate eggs. Increase in the swimming capacity of fish larvae, the opening of the 
mouth and the width of the gut improved the success of capturing and ingesting larger prey (Checkley, 1982; Haslob et al., 2009; Kiørboe et al., 1985; Munk, 1992; Munk and Kiørboe, 1985). Ingestion of large copepods with higher carbon content (Peters, 1983) better fulfils the higher energetic requirements of larger larvae. The relevance of invertebrate eggs through their positive selection was also observed for other subpopulations (Blaxter, 1965; Cohen and Lough, 1983; Fox et al., 1999; Marshall et al., 1937) even if Conway et al. (1994) showed that fish larvae have limited digestion capacities of copepod eggs. Observed eggs can also be remaining elements of one or several ingested ovigerous copepods.

\section{Negative effect of winter conditions on larval diet?}

The vacuity rate of Downs herring larvae (45\%) is relatively low compared to previous studies at the same period either in the same area, (61\%; Lebour, 1924) or in other areas like in the Clyde Sea (70\%; Marshall et al., 1937), Georges Bank (51\%; Cohen and Lough, 1983) and Pärnu Bay (30-80\%; Arula et al., 2012). Whereas larval herring from the Irish Sea had a vacuity rate of $17 \%$ (Checkley, 1982), these larvae were fed in experimental conditions which are usually more than optimal and unrealistic compared to those experienced by Downs herring larvae in winter. It is also comparable to field studies during spring (29-75\%; Fox et al., 1999) and autumn in other area like Northern North Sea (55\%; Heath et al., 1989) and other species like sole (42-55\%; Grioche, 1998), plaice (40\%; Shelbourne, 1957) and sand-eel (32-41\%; Ryland, 1964). The comparable (sometimes even lower) values of vacuity rate observed for Downs herring larvae suggest that these larvae are not more limited by winter trophic conditions than spring larvae could be during the planktonic bloom. The less productive conditions of winter experienced by Downs herring larvae might be counterbalanced by a lower number of winter species 
larvae, hence ensuring less competition for food and an equivalent level of nutrition as the one experienced by larvae during spring. Downs herring larvae might also diversify their diet in order to support less productive conditions of winter. Arula et al., (2012) suggested that a diversified diet allows for adapting to inter-annual fluctuations of prey composition in the sea.

\section{Identification of the critical period}

Following Hjort (1914), the "critical period" hypothesis states that the year-class strength in fish populations is determined during the larval phase when fish larvae pass from an endogenous nutrition to an exogenous nutrition. Recently, it has been shown to occur during the first 20-30 days (Fässler et al., 2011; Hufnagl et al., 2015) for larval herring in the North Sea. During this period, the present study identified two peaks of higher vacuity rate. The peak (74\%) observed for larvae of $8 \mathrm{~mm}$ is in agreement with their yolk-sac nutrition. The vacuity rate decreased at a size of $9 \mathrm{~mm}$, which indicates an active feeding linked to the yolk sac absorption (Heath and MacLachlan, 1987; Lebour, 1924). Up to 13 $\mathrm{mm}$, the vacuity rate remained constant between 30 and $40 \%$. The other peak $(56 \%)$ of vacuity rate which occurs at $13 \mathrm{~mm}$ suggests some difficulties for these larvae to feed and corresponded to the shift observed in the prey composition. Rather than the yolkabsorption period, we assume that this ontogenetic shift in term of prey preference constitutes the critical period for Downs herring larvae. Change in their food habit will make than need some time to adapt to their new zooplanktonic prey which are potentially less abundant and more difficult to capture than protist.

\section{Conclusion}


The present study 1) demonstrated the usefulness of SEM to study the diet of young Downs herring larvae, 2) characterised the omnivorous diet of these larvae in term of prey composition and vacuity rate and 3) identified a critical period at a size of $13 \mathrm{~mm}$ linked to a shift in prey preferences.

Direct observation of gut contents could be completed in future studies using indirect approaches including bar coding (Riemann et al., 2010), fatty acids (Giraldo et al., 2015) and stable isotopes (Fry, 1988) composition of prey and larvae. Moreover, determination of the diet composition as well as the feeding activity, even if required, are not sufficient and do not inform on the impact of the feeding strategy of these larvae on their nutritional status and physiological condition. This is a critical step that should be considered and might be achieved using larval condition indices (Bergeron, 1997; Buckley, 1984) that were developed and applied to experimentally fed larvae (Folkvord et al., 1996; Peck et al., 2015) but rarely on in-situ caught larvae (McGurk et al., 1992).

\section{Acknowledgements}

The authors would like to acknowledge IFREMER and the Pôle Métropolitain de la Côte d'Opale for their financial supports. They also would like to thank the scientific staff and crew of the RV Thalassa involved each year in the IBTS survey. Finally, the authors are very grateful to the two anonymous referees and the editor, who helped to greatly improve the initial manuscript with their positive and constructive comments.

\section{References}

Alvarez-Fernandez, S., Lindeboom, H., Meesters, E., 2012. Temporal changes in plankton of the North Sea: community shifts and environmental drivers. Mar. Ecol. Prog. Ser. 462, 21-38. doi:10.3354/meps09817 
Amundsen, P.-A., Gabler, H.-M., Staldvik, F.J., 1996. A new approach to graphical analysis of feeding strategy from stomach contents data-modification of the Costello (1990) method. J. Fish Biol. 48, 607-614.

Arula, T., Kotta, J., Lankov, A., Simm, M., Põlme, S., 2012. Diet composition and feeding activity of larval spring-spawning herring: Importance of environmental variability. J. Sea Res. 68, 33-40. doi:10.1016/j.seares.2011.12.003

Bacha, M., Amara, R., 2009. Spatial, temporal and ontogenetic variation in diet of anchovy (Engraulis encrasicolus) on the Algerian coast (SW Mediterranean). Estuar. Coast. Shelf Sci. 85, 257-264. doi:10.1016/j.ecss.2009.08.009

Baker, R., Buckland, A., Sheaves, M., 2014. Fish gut content analysis: robust measures of diet composition. Fish Fish. 15, 170-177. doi:10.1111/faf.12026

Beaugrand, G., Brander, K.M., Lindley, J.A., Souissi, S., Reid, P.C., 2003. Plankton effect on cod recriutment in the North Sea. Nature 426, 661-664.

Becker, G.A., Pauly, M., 1996. Sea surface temperature changes in the North Sea and their causes. ICES J. Mar. Sci. J. Cons. 53, 887-898.

Berg, J., 1979. Discussion of methods of investigating the food of fishes, with reference to a preliminary study of the prey of Gobiusculus flavescens (Gobiidae). Mar. Biol. $50,263-273$.

Bergeron, J.-P., 2009. Nutritional condition of anchovy Engraulis encrasicolus larvae in connection with mesozooplankton feeding catabolism in the southern Bay of Biscay, NE Atlantic. J. Exp. Mar. Biol. Ecol. 377, 76-83. doi:10.1016/j.jembe.2009.06.019

Bergeron, J.-P., 1997. Nucleic acids in ichthyoplankton ecology: a review, with emphasis on recent advances for new perspectives. J. Fish Biol. 51, 284-302. 
Bjørke, H., 1976. Food and feeding of young herring larvae of Norwegian spring spawners. ICES.

Blaxter, J.H.S., 1965. The feeding of herring larvae and their ecology in relation to feeding. Calif Coop Ocean. Fish Invest Rep 10, 79-88.

Braven, J., Butler, E.I., Chapman, J., Evens, R., 1995. Changes in dissolved free amino acid composition in sea water associated with phytoplankton populations. Sci. Total Environ. 172, 145-150.

Buckley, L.J., 1984. RNA-DNA ratio: an index of larval fish growth in the sea. Mar. Biol. 80, 291-298.

Cahu, C.L., Infante, J.Z., Peres, A., Quazuguel, P., Le Gall, M.M., 1998. Algal addition in sea bass (Dicentrarchus labrax) larvae rearing: effect on digestive enzymes. Aquaculture 161, 479-489.

Catalán, I.A., Folkvord, A., Palomera, I., Quílez-Badía, G., Kallianoti, F., Tselepides, A., Kallianotis, A., 2010. Growth and feeding patterns of European anchovy (Engraulis encrasicolus) early life stages in the Aegean Sea (NE Mediterranean). Estuar. Coast. Shelf Sci. 86, 299-312. doi:10.1016/j.ecss.2009.11.033

Checkley, D.M., 1982. Selective feeding by Atlantic herring (Clupea harengus) larvae on zooplankton in natural assemblages. Mar Ecol Prog Ser 9, 245-253.

Cohen, R.E., Lough, R.G., 1983. Prey field of larval herring Clupea harengus on a continental shelf spawning area. Can. J. Fish. Aquat. Sci. 46, 624-632.

Conway, D.V.P., McFadzen, I.R.B., Tranter, P.R.G., 1994. Digestion of copepod eggs by larval turbot Scophthalmus maximus and egg viability following gut passage. Mar. Ecol. Prog. Ser. 106, 303-309.

Corten, A., 2013. Recruitment depressions in North Sea herring. ICES J. Mar. Sci. 70, 115. doi:10.1093/icesjms/fss187 
Corten, A., 1986. On the causes of the recruitment failure of herring in the central and northern North Sea in the years 1972-1978. J. Cons. 42, 281-294.

Cushing, D.H., 1969. The regularity of the spawning season of some fishes. J. Cons. 33, $81-92$.

Davis, A.M., Blanchette, M.L., Pusey, B.J., Jardine, T.D., Pearson, R.G., 2012. Gut content and stable isotope analyses provide complementary understanding of ontogenetic dietary shifts and trophic relationships among fishes in a tropical river: Isotopic ecology of some tropical fishes. Freshw. Biol. 57, 2156-2172. doi:10.1111/j.1365-2427.2012.02858.x

de Figueiredo, G.M., Nash, R.D.M., Montagnes, D.J.S., 2007. Do protozoa contribute significantly to the diet of larval fish in the Irish Sea? J. Mar. Biol. Assoc. UK 87, 843. doi:10.1017/S002531540705713X

de Figueiredo, G.M., Nash, R.D.M., Montagnes, D.J.S., 2005. The role of the generally unrecognised microprey source as food for larval fish in the Irish Sea. Mar. Biol. 148, 395-404. doi:10.1007/s00227-005-0088-0

Dower, J.F., Pepin, P., Leggett, W.C., 1998. Enhanced gut fullness and an apparent shift in size selectivity by radiated shanny (Ulvaria subbifurcata) larvae in response to increased turbulence. Can. J. Fish. Aquat. Sci. 55, 128-142.

Duarte, L.O., García, C.B., 2004. Trophic role of small pelagic fishes in a tropical upwelling ecosystem. Ecol. Model. 172, 323-338. doi:10.1016/j.ecolmodel.2003.09.014

Fässler, S.M.M., Payne, M.R., Brunel, T., Dickey-Collas, M., 2011. Does larval mortality influence population dynamics? An analysis of North Sea herring (Clupea harengus) time series: North Sea herring larval mortality. Fish. Oceanogr. 20, 530543. doi:10.1111/j.1365-2419.2011.00600.x 
Fauchald, P., Skov, H., Skern-Mauritzen, M., Johns, D., Tveraa, T., 2011. Wasp-Waist Interactions in the North Sea Ecosystem. PLoS ONE 6, e22729. doi:10.1371/journal.pone.0022729

Folkvord, A., Ystanes, L., Johannessen, A., Moksness, E., 1996. RNA: DNA ratios and growth of herring (Clupea harengus) larvae reared in mesocosms. Mar. Biol. 126, $591-602$.

Fossum, P., Johannessen, A., 1979. Field and laboratory studies of herring larvae (Clupea harengus L.). ICES.

Fox, C.J., 1996. Length changes in herring (Clupea harengus) larvae: effects of capture and storage in formaldehyde and alcohol. J. Plankton Res. 18, 483-493.

Fox, C.J., Harrop, R., Wimpenny, A., 1999. Feeding ecology of herring (Clupea harengus) larvae in the turbid Blackwater Estuary. Mar. Biol. 134, 353-365.

Fry, B., 1988. Food web structure on Georges Bank from stable C, N, S isotopic compositions. Limnol. Oceanogr. 33, 1182-1190.

Fukami, K., Watanabe, A., Fujita, S., Yamaoka, K., Nishijima, T., 1999. Predation on naked protozoan microzooplankton by fish larvae. Mar Ecol Prog Ser 185, 285291.

Gasparini, S., 2007. PLANKTON IDENTIFIER, a software for automatic recognition of planktonic organisms.

Giraldo, C., Mayzaud, P., Tavernier, E., Boutoute, M., Penot, F., Koubbi, P., 2015. Lipid dynamics and trophic patterns in Pleuragramma antarctica life stages. Antarct. Sci. 27, 429-438. doi:10.1017/S0954102015000036

Gorsky, G., Ohman, M.D., Picheral, M., Gasparini, S., Stemmann, L., Romagnan, J.-B., Cawood, A., Pesant, S., Garcia-Comas, C., Prejger, F., 2010. Digital zooplankton 
image analysis using the ZooScan integrated system. J. Plankton Res. 32, 285-303. doi:10.1093/plankt/fbp124

Gosselin, S., Fortier, L., Gagné, J.A., 1989. Vulnerability of marine fish larvae to the toxic dinoflagellate Protogonyaulax tamarensis. Mar. Ecol. Prog. Ser., Oldendorf 57, 110.

Grioche, A., 1998. Dynamique de l'écophase ichtyoplanctonique en Manche orientale et sud Mer du Nord. Approche multispécifique et description de deux espèces cibles : Solea solea (L.) et Pleuronectes flesus (L.). Université du Littoral Côte d'Opale.

Grosjean, P., Picheral, M., Warembourg, C., Gorsky, G., 2004. Enumeration, measurement, and identification of net zooplankton samples using the ZOOSCAN digital imaging system. ICES J. Mar. Sci. 61, 518-525. doi:10.1016/j.icesjms.2004.03.012

Harden-Jones, F.R., 1968. Fish migration., St. Martin’s. ed. New York.

Haslob, H., Rohlf, N., Schnack, D., 2009. Small scale distribution patterns and vertical migration of North Sea herring larvae (Clupea harengus, Teleostei: Clupeidea) in relation to abiotic and biotic factors. Sci. Mar. 73, 13-22. doi:10.3989/scimar.2009.73s1013

Hay, D.E., 1981. Effects of capture and fixation on gut contents and body size of Pacific herring larvae. Rapp P-V Réun Cons Int Explor Mer 178, 395-400.

Heath, M., 1993. An evaluation and review of the ICES herring larval surveys in the North Sea and adjacent waters. Bull. Mar. Sci. 53, 795-817.

Heath, M., Leaver, M., Matthews, A., Nicoll, N., 1989. Dispersion and feeding of larval herring (Clupea harengus L.) in the Moray Firth during September 1985. Estuar. Coast. Shelf Sci. 28, 549-566. 
Heath, M., Scott, B., Bryant, A.D., 1997. Modelling the growth of herring from four different stocks in the North Sea. J. Sea Res. 38, 413-436.

Heath, M.R., MacLachlan, P., 1987. Dispersion and mortality of yolk-sac herring (Clupea harengus L.) larvae from a spawning ground to the west of the Outer Hebrides. J. Plankton Res. 9, 613-630.

Hjelmeland, K., Pedersen, B.H., Nilssen, E.M., 1988. Trypsin content in intestines of herring larvae, Clupea harengus, ingesting inert polystyrene spheres or live crustacea prey. Mar. Biol. 98, 331-335.

Hjort, J., 1914. Fluctuations in the great Fisheries of Northern Europe viewed in the Light of biological Research. ICES J. Mar. Sci. 20, 1-228.

Houde, E.D., 2008. Emerging from Hjort's Shadow. J. Northwest Atl. Fish. Sci. 41, 53-70. doi:10.2960/J.v41.m634

Hufnagl, M., Peck, M.A., 2011. Physiological individual-based modelling of larval Atlantic herring (Clupea harengus) foraging and growth: insights on climate-driven life-history scheduling. ICES J. Mar. Sci. 68, 1170-1188. doi:10.1093/icesjms/fsr078

Hufnagl, M., Peck, M.A., Nash, R.D.M., Dickey-Collas, M., 2015. Unravelling the Gordian knot! Key processes impacting overwintering larval survival and growth: A North Sea herring case study. Prog. Oceanogr. 138, 486-503. doi:10.1016/j.pocean.2014.04.029

Hunt von Herbing, I., Gallager, S.M., 2000. Foraging behavior in early Atlantic cod larvae (Gadus morhua) feeding on a protozoan (Balanion sp.) and a copepod nauplius (Pseudodiaptomus sp.). Mar. Biol. 136, 591-602.

Hunt von Herbing, I., Gallager, S.M., Halteman, W., 2001. Metabolic costs of pursuit and attack in early larval Atlantic cod. Mar. Ecol. Prog. Ser. 216, 201-212. 
Huntley, M., 1989. Larval feeding of northern anchovy, Engraulis mordax, on dinoflagellates: Implications for year-class strength. SCI MAR 53, 239-245.

Hyslop, E.J., 1980. Stomach contents analysis-a review of methods and their application. J. Fish Biol. 17, 411-429.

ICES, 2015. Report of the Herring Assessment Working Group for the Area South of $62^{\circ} \mathrm{N}$ (HAWG). ICES HQ, Copenhagen, Denmark, p. 850.

Iles, T.D., Sinclair, M., 1982. Atlantic herring, stock discreteness and abundance. Science $215,627-33$.

Illing, B., Moyano, M., Niemax, J., Peck, M.A., 2015. Direct Effects of Microalgae and Protists on Herring (Clupea harengus) Yolk Sac Larvae. PloS One 10, e0129344. Jacobs, J., 1974. Quantitative measurement of food selection. Oecologia 14, 413-417.

Kiørboe, T., Munk, P., Støttrup, J.G., 1985. First feeding by larval herring Clupea harengus L. Dana 5, 95-107.

Koubbi, P., Vallet, C., Razouls, S., Grioche, A., Hilde, D., Courcot, L., Janquin, M.A., Vacchi, M., Hureau, J.C., 2007. Condition and diet of larval Pleuragramma antarcticum (Nototheniidae) from Terre Adélie (Antarctica) during summer. Cybium 31, 67-76.

Landaeta, M.F., Ochoa-Muñoz, M.J., Bustos, C.A., 2014. Feeding success and selectivity of larval anchoveta Engraulis ringens in a fjord-type inlet from northern Patagonia (Southeast Pacific). Rev. Biol. Mar. Oceanogr. 49, 461-475. doi:10.4067/S071819572014000300005

Lasker, R., 1975. Field criteria for survival of anchovy larvae: the relation between inshore chlorophyll maximum layers and successful first feeding. Fish. Bull. 73, 453-462.

Lê, S., Josse, J., Husson, F., 2008. FactoMineR, An R Package for Multivariate Analysis. J. Stat. Softw. 25, 1-18. 
Lebour, M.V., 1924. The food of young herring. J. Mar. Biol., Ass. U.K. 13, 325-30.

Lebour, M.V., 1921. The food of young clupeoids. J. Mar. Biol., Ass. U.K., 12, 458-67.

Legendre, P., Legendre, L.F., 2012. Numerical ecology, Elsevier. ed.

Lelievre, S., Verrez-Bagnis, V., Jerome, M., Vaz, S., 2010. PCR-RFLP analyses of formalin-fixed fish eggs for the mapping of spawning areas in the Eastern Channel and Southern North Sea. J. Plankton Res. 32, 1527-1539. doi:10.1093/plankt/fbq067

Lorenzen, C.J., 1967. Determination of chlorophyll and pheo-pigments: spectrophotometric equations. Limnol. Oceanogr. 12, 343-346.

Marshall, S.M., Nicholls, A.G., Orr, A.P., 1937. On the growth and feeding of the larval and post-larval stages of the Clyde herring. J. Mar. Biol. Assoc. U. K. 22, 245-267.

Maucorps, A., 1969. Biologie et pêche du hareng en mer du nord, son exploitation rationnelle. Sci. Pêche 186, 1-8.

McGurk, M.D., Warburton, H.D., Galbraith, M., Kusser, W.C., 1992. RNA-DNA ratio of herring and sand lance larvae from Port Moller, Alaska: comparison with prey concentration and temperature. Fish. Oceanogr. 1, 193-207.

Montagnes, D.J.S., Dower, J.F., Figueiredo, G.M., 2010. The ProtozooplanktonIchthyoplankton Trophic Link: An Overlooked Aspect of Aquatic Food Webs. J. Eukaryot. Microbiol. doi:10.1111/j.1550-7408.2010.00476.x

Motoda, S., 1959. Devices of simple plankton apparatus. Mem. Fac. Fish. Hokkaido Univ. 7, 73-94.

Munk, P., 1992. Foraging behaviour and prey size spectra of larval herring Clupea harengus. Mar. Ecol.-Prog. Ser. 80, 149-158. 
Munk, P., Kiørboe, T., 1985. Feeding behaviour and swimming activity of larval herring(Clupea harengus) in relation to density of copepod nauplii. Mar. Ecol. Prog. Ser. Oldendorf 24, 15-21.

Munk, P., Kiørboe, T., Christensen, V., 1989. Vertical migrations of herring, Clupea harengus, larvae in relation to light and prey distribution. Environ. Biol. Fishes 26, $87-96$.

Nagano, N., Iwatsuki, Y., Kamiyama, T., Nakata, H., 2000. Effects of marine ciliates on survivability of the first-feeding larval surgeonfish, Paracanthurus hepatus: laboratory rearing experiments. Hydrobiologia 432, 149-157.

Nash, R.D.M., Dickey-Collas, M., 2005. The influence of life history dynamics and environment on the determination of year class strength in North Sea herring (Clupea harengus L.). Fish. Oceanogr. 14, 279-291.

Ohman, M.D., Theilacker, G.H., Kaupp, S.E., 1991. Immunochemical Detection of Predation on Ciliate Protists by Larvae of the Northern Anchovy (Engraulis mordax). Biol. Bull. 181, 500. doi:10.2307/1542370

Paerl, H.W., Shimp, S.L., 1973. Preparation of filtered plankton and detritus for study with scanning electron microscopy1. Limnol. Oceanogr. 18, 802-805.

Payne, M., Stine, D., Worsøe Clausen, L., Munk, P., Mosegaard, H., Nash, R., 2013. Recruitment decline in North Sea herring is accompanied by reduced larval growth rates. Mar. Ecol. Prog. Ser. 489, 197-211. doi:10.3354/meps 10392

Payne, M.R., 2010. Mind the gaps: a state-space model for analysing the dynamics of North Sea herring spawning components. ICES J. Mar. Sci. J. Cons. 67, 19391947.

Payne, M.R., Hatfield, E.M., Dickey-Collas, M., Falkenhaug, T., Gallego, A., Gröger, J., Licandro, P., Llope, M., Munk, P., Röckmann, C., 2009. Recruitment in a changing 
environment: the 2000s North Sea herring recruitment failure. ICES J. Mar. Sci. J. Cons. 66, 272-277.

Pebesma, E.J., 2004. Multivariable geostatistics in S, the gstat package. Comput. Geosci. $30,683-691$.

Peck, M.A., Baumann, H., Clemmesen, C., Herrmann, J.-P., Moyano, M., Temming, A., 2015. Calibrating and comparing somatic-, nucleic acid-, and otolith-based indicators of growth and condition in young juvenile European sprat (Sprattus sprattus). J. Exp. Mar. Biol. Ecol. 471, 217-225. doi:10.1016/j.jembe.2015.06.011

Pedersen, B.H., 1984. The intestinal evacuation rates of larval herring (Clupea harengus L.) predating on wild plankton. Dana 3, 1-30.

Pepin, P., Dower, J.F., 2007. Variability in the trophic position of larval fish in a coastal pelagic ecosystem based on stable isotope analysis. J. Plankton Res. 29, 727-737. doi:10.1093/plankt/fbm052

Peters, R.H., 1983. The ecological implications of body size., Cambridge Univ. Press. ed.

Petitgas, P., Rijnsdorp, A.D., Dickey-Collas, M., Engelhard, G.H., Peck, M.A., Pinnegar, J.K., Drinkwater, K., Huret, M., Nash, R.D.M., 2013. Impacts of climate change on the complex life cycles of fish. Fish. Oceanogr. 22, 121-139. doi:10.1111/fog. 12010

Reitan, K.I., Rainuzzo, J.R., Øie, G., Olsen, Y., 1997. A review of the nutritional effects of algae in marine fish larvae. Aquaculture 155, 207-221.

Riemann, L., Alfredsson, H., Hansen, M.M., Als, T.D., Nielsen, T.G., Munk, P., Aarestrup, K., Maes, G.E., Sparholt, H., Petersen, M.I., Bachler, M., Castonguay, M., 2010. Qualitative assessment of the diet of European eel larvae in the Sargasso Sea resolved by DNA barcoding. Biol. Lett. 6, 819-822. doi:10.1098/rsbl.2010.0411 
Robert, D., Levesque, K., Gagne, J.A., Fortier, L., 2011. Change in prey selectivity during the larval life of Atlantic cod in the southern Gulf of St Lawrence. J. Plankton Res. 33, 195-200. doi:10.1093/plankt/fbq095

Robineau, B., Gagné, J.A., Fortier, L., Cembella, A.D., 1991. Potential impact of a toxic dinoflagellate (Alexandrium excavatum) bloom on survival of fish and crustacean larvae. Mar. Biol. 108, 293-301. doi:10.1007/BF01344344

Russell, F.S., 1976. The Eggs and Planktonic Stages of British Marine Fishes. Academic Press, London.

Ryland, J.S., 1964. The feeding of plaice and sand-eel larvae in the southern North Sea. J. Mar. Biol. Assoc. U. K. 44, 343-364.

Shelbourne, J.E., 1957. The feeding and condition of plaice larvae in good and bad plankton patches. J Mar Biol UK 36, 539-552.

St. John, M., Clemmesen, C., Lund, T., Köster, T., 2001. Diatom production in the marine environment: implications for larval fish growth and condition. ICES J. Mar. Sci. 58, 1106-1113. doi:10.1006/jmsc.2001.1089

Strickland, J.D., Parsons, T.R., 1972. A practical handbook of seawater analysis.

Theilacker, G.H., Bailey, K.M., Canino, M.F., Porter, S.M., 1996. Variations in larval walleye pollock feeding and condition: a synthesis. Fish. Oceanogr. 5, 112-123.

Utermöhl, H., 1958. Zur vervollkommnung der quantitativen phytoplankton-methodik. Mitt Int Ver Theor Angew Limnol 9, 1-38.

Vallet, C., Beans, C., Koubbi, P., Courcot, L., Hecq, J.-H., Goffart, A., 2011. Food preferences of larvae of Antarctic silverfish Pleuragramma antarcticum Boulenger, 1902 from Terre Adélie coastal waters during summer 2004. Polar Sci. 5, 239-251. doi:10.1016/j.polar.2010.12.005 